This article was downloaded by: [julie-anne Boudreau]

On: 25 July 2015, At: 11:24

Publisher: Routledge

Informa Ltd Registered in England and Wales Registered Number: 1072954 Registered

office: 5 Howick Place, London, SW1P 1WG

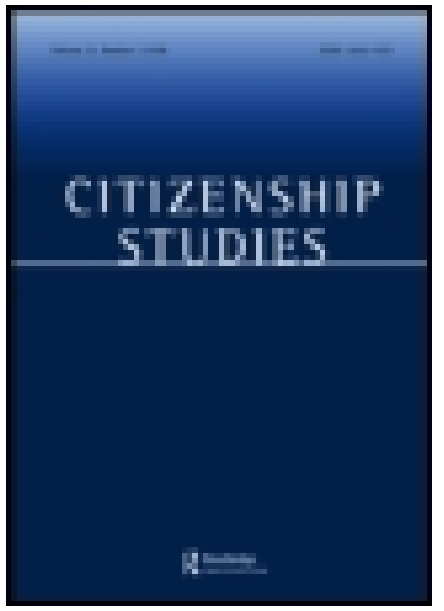

\section{Citizenship Studies}

Publication details, including instructions for authors and subscription information: http:// www. tandfonline.com/loi/ ccst20

\section{Fear and youth citizenship practices: insights from Montreal}

Julie-Anne Boudreau ${ }^{a}$, Marilena Liguori ${ }^{a} \&$ Maude Séguin-Manegre ${ }^{a}$

${ }^{a}$ Institut National de la Recherche Scientifique, Montréal, Quebéc, Canada

Published online: 24 J ul 2015.

\title{
CrossMark
}

Click for updates

To cite this article: J ulie-Anne Boudreau, Marilena Liguori \& Maude Séguin-Manegre (2015): Fear and youth citizenship practices: insights from Montreal, Citizenship Studies, DOI: 10.1080/ 13621025.2015.1006177

To link to this article: http:// dx. doi.org/ 10.1080/13621025.2015.1006177

\section{PLEASE SCROLL DOWN FOR ARTICLE}

Taylor \& Francis makes every effort to ensure the accuracy of all the information (the "Content") contained in the publications on our platform. However, Taylor \& Francis, our agents, and our licensors make no representations or warranties whatsoever as to the accuracy, completeness, or suitability for any purpose of the Content. Any opinions and views expressed in this publication are the opinions and views of the authors, and are not the views of or endorsed by Taylor \& Francis. The accuracy of the Content should not be relied upon and should be independently verified with primary sources of information. Taylor and Francis shall not be liable for any losses, actions, claims, proceedings, demands, costs, expenses, damages, and other liabilities whatsoever or howsoever caused arising directly or indirectly in connection with, in relation to or arising out of the use of the Content.

This article may be used for research, teaching, and private study purposes. Any substantial or systematic reproduction, redistribution, reselling, loan, sub-licensing, systematic supply, or distribution in any form to anyone is expressly forbidden. Terms \& 
Conditions of access and use can be found at http://www.tandfonline.com/page/termsand-conditions 


\title{
Fear and youth citizenship practices: insights from Montreal
}

\author{
Julie-Anne Boudreau*, Marilena Liguori and Maude Séguin-Manegre \\ Institut National de la Recherche Scientifique, Montréal, Quebéc, Canada
}

(Received 3 April 2014; accepted 16 November 2014)

\begin{abstract}
This article explores how fear contributes to empowerment and citizenship practices among youth who choose alternative lifestyles. Fear is conceived in a threefold manner: (1) as a manipulated resource in the political process, (2) as energy to be tamed through individual will, and (3) as radiating from actors and flowing through situations of action. Through an examination of how 'risk-taking' youths play with fear, the article critically reflects on the modern and advanced modern conceptualizations of the political 'heroic' actor and its articulation with an understanding of political action as decentered from human actors. Citizenship practices, it is argued, operate on five distinct levels of political engagement ranging from an awareness of the world outside of oneself to empathy for others and activism. Rather than being state-centered, the article develops an understanding of intersubjective citizenship based on affective memory.
\end{abstract}

Keywords: citizenship practices; fear; risk; youth; political engagement; alternative lifestyles; aesthetic relations; affective memory

\begin{abstract}
Youth thus become objects of collective fear, seen not as individuals but for the anxieties they cause and the jarring cultural changes they are seen to embrace. The particular impulsiveness of youths, wrapped up in their hostility to tradition and authority, only serves to aggravate these tensions. (Ungar 2009, 208)

With this invention - and later that of pre-teens and post-teens, to extend upstream and downstream - we slowly but surely go from a social bipartition (children and adults) to a tripartition. In this sense, the teenager modifies sociability at all institutional levels, from the family to the nation. S/he is an agitator, almost in a chemical sense - and this is also his/her richness. S/he is also a target, in a more political sense. (Goguel d'Allondans 2004, 262, our translation)
\end{abstract}

In many cities, collective fears tend to crystallize around youth, particularly racialized male youth. The cases of recent shootings of unarmed black youth in the USA (for example, Trayvon Martin in Florida and Michael Brown in Missouri) have brought these issues into the spotlight and Montreal is no exception as it has seen its share of altercations between youth and the police. Young people have become the target of disciplining and surveillance policies, from by-laws against them 'hanging out' in public spaces to the repression of alternative youth lifestyles (for example, living on the street, extreme sports in urban settings, and political activism), or from racial profiling techniques targeting street gangs to the plethora of social engineering programs aimed at pushing youth in 'socially acceptable' activities. As a socially constructed category, youth tend to be seen as agitators and hostile to authority. ${ }^{1}$ Because they often disturb the established order, they generate fear.

*Corresponding author. Email: Julie-anne.boudreau@ucs.inrs.ca 
Fear $^{2}$ is relational and subject to change. One cannot simply look at disciplining strategies and social control in order to understand how fear operates in the city. It is necessary to also look at how fear can provide a feeling of empowerment and how social control and empowerment are not always mutually exclusive. We propose here to understand fear as an aesthetic relation to the state: like power it cannot be monopolized or controlled by a single group. According to Postrel (2003, 6), '[a]esthetics is the way we communicate through the senses. It is the art of creating reactions without words, through the look and feel of people, places, and things.' Fear is a relational flow aesthetically connecting young people to the city, to other dwellers, and to authorities, often through non-verbal means. When fear circulates as an affective flow between them, youth mutually adjust and are often guided by their intuition. The cumulative collective experience of youth constructs a group story - a common identity characterized by what Lyng (1990) calls 'experimental anarchy.' The anti-conformist ideas and lifestyle choices of young people, as well as their search for self and group fulfillment through fear, constitute 'acts of citizenship' (Isin 2008), not only because they are statements against mainstream values, but mostly because they aim to change things around them by legitimizing new ways of living the city. As Wilkins $(2008,2)$ notes in her study on subcultures, adopting an alternative lifestyle, be it through the activities one practices or the clothing one chooses to wear, can be a way 'to manage success and failure, risk and security, membership and personal identity'.

This article explores how fear has agentic power for youths who choose alternative lifestyles and how it contributes to the unfolding of citizenship practices. We interviewed youth who belong to dominant cultural groups but who choose not to conform to mainstream societal values, thus contesting social control mechanisms. They take part in activities that they see as going against conventional norms, including voluntarily living on the street, being a graffiti artist, practicing extreme sports in urban settings, dumpster diving, urban explorations of abandoned buildings, and climbing buildings for Greenpeace. ${ }^{3}$ In speaking to these youth, we aim to better understand what is the role of risk and fear in their constructed identity, how does it translate into specific lifestyles and political claims, and how does it influence their citizenship practices?

In order to analyze such practices, the article calls for a more open conceptualization of citizenship, particularly in urban settings. By looking at youth engaged in activities involving a certain degree of risk (for example, extreme sports that may cause bodily harm or other activities with legal or moral repercussions), we explore how the process of resisting, transforming, and operating around the discourses and feelings of fear, enables youth to construct alternative legitimacies, group empowerment, and citizenship practices. The article discusses how these alternative legitimacies result from ambivalent responses to social control and are characterized by more fluid forms of belonging than what is usually recognized in conceptions of formal (statist) citizenship.

There is a fairly large literature on the practice of extreme sports in the city, but we know much less of other urban activities that involve a certain degree of risk, particularly politicized activities. There is a literature on emotion management and emotional regulation, which is also central to explorations of fear in social movements, but is not explicitly connected to urban environments. The 1990s debate on urban citizenship has theoretically opened the formal conceptualization of citizenship to city-ness, but it remains state-centered and thus falls short of recognizing alternative forms of citizenship practices. This article thus begins with a critical review of these literatures, before exploring more closely the fear dynamics of youth experience with risk-taking in Montreal. In the last section, we suggest that such urban explorations and experiences of 'displacement' 
(putting oneself in an uncomfortable situation of unfamiliarity and risk) bring about feelings of self-realization. The participants' presentation of themselves as anti-conformist youth shapes their political subjectivity and generates specific forms of citizenship practices.

\section{Urban citizenship, 'risky' behavior, fear, and politics}

Much has been written in this journal about the notion of citizenship. We do not recall here the evolution of these stimulating theoretical debates, but rather we wish to revisit a fairly marginal aspect of these discussions. Ideas of urban citizenship flourished in the 1990s as the rise of anti-globalization movements inspired research on the dialectic between global and local as new sites of resistance (e.g. Hamel, Lustiger-Thaler, and Mayer 2000; Köhler and Wissen 2003; Conway 2004). The interplay of these different clusters of 'glocal' movements, from Occupy to the Indignados, from the Social Fora to localized antigentrification struggles, has created a novel multiscalar and transnational architecture of urban protest. This has put the 'right to the city' to the forefront of social and political agendas. $^{4}$

The notion of urban citizenship stresses the importance of recognizing the legitimacy of political action for people without formal citizenship (Holston 1995; Holston and Appadurai 1996; Sassen 1996; Dikeç and Gilbert 2002; Mitchell 2003). The right to be politically active even without legal citizenship status brings to the fore the issue of the possibility or ability to act. These studies locate political mobilization in everyday life, because people inhabit a world in which they wish to act. However, by focusing on the legitimacy to act politically without formal citizenship, this literature remains unable to explain why people decide to act (Boudreau, Boucher, and Liguori 2009). This shortcoming can be explained by the state-centrism of the urban citizenship literature, which focuses on claiming rights to the city.

But the youths with whom we spoke do not care much about claiming rights. Why then do they decide to act as 'alternative' citizens'? What sorts of citizenship practices do they exhibit? They often opt for negotiation or avoidance in their relation to the state (this is most evident in their relationship to police officers, but it is also evident in their relation to moral authorities more generally). Youths often adopt an attitude of distancing in order to create (sometimes by illicit means) a space for action. Rather than seeing such distancing as a means to 'opt out' of citizenship action, we would suggest that this space of action points to another type of relation to the state, which we may call intersubjective citizenship. Citizenship would thus imply a legal and affective link to the state and the nation, but also and most importantly for this article, an ensemble of political relationships (contesting social control and negotiating with authorities) that are based on daily practices grounded in alternative lifestyles.

Isin (2008) suggests that citizenship practices are composed of citizenship acts, that is, creative moments that break from routine actions and, through its unfolding, legitimate the actor. An 'act' is not a reaction to a situation, but the creation of an actor who can legitimately be present in the situation she/he participates in creating. The practices we saw in this research are indeed characterized by creative ruptures from routine action and provide feelings of self-realization enabling youths to constitute themselves as actors. While most conceptions of citizenship would not see these acts as 'political', this article suggests otherwise.

An intersubjective conception of citizenship implies decentering 'citizenship' from the sovereign powers of the state, and conceiving it as specific social practices through which 
power is implemented. This means tearing down the strong opposition between governing and governed people which was still characteristic of the urban citizenship literature.

Political action in the city is deeply entrenched into everyday life, which means that it is largely defined by interdependencies, unpredictability, and non-strategic actions (Boudreau 2010). In other words, this article suggests that in an urban context and as a set of political relationships to the state, citizenship practices are not only marked by strategic claiming and contention. Indeed, an act of citizenship is a relational act that can be solidaristic (generous, understanding), agonistic (competitive, combative), alienating (revengeful, hostile) (Isin 2008, 19), or we would add aesthetic (sensual, intuitive). The focus here is on aesthetic relations to the city and to the state. More specifically, we explore the role of fear in the unfolding of these relations characterizing citizenship practices.

There is a large literature on the role of fear in politics (for instance, Marcus 2000; Furedi 2005). Many of these studies focus on the influence of the post-9/11 climate of fear on state action (Sorkin and Zukin 2002; Robin 2004). Others are grounded in the sociology of social movement and attempt to understand how fear affects mobilization and the experience of activists (Yang 2000; Goodwin and Pfaff 2001). These studies emphasize how fear propels collective action. Barbalet (1995), for instance, explores how fear and hope participate in the constitution of interest and the direction of action. He insists on the intersubjectivity of fear, its relationality. With the concept of 'emotional climate', he argues that fear does not merely lead to flight or fight, subjugation or rebellion, but also to 'the containment of negative prospects perceived as constituting a threat to their interests' (Barbalet 1995, 31).

While this literature is useful to understand the mechanisms through which fear 'causes' political action and how these mechanisms are culturally and historically sensitive, we see from our interview material (discussed later) that such anthropocentrism is insufficient to capture the political agency of fear. A growing literature on political affect, largely influenced by non-representational theory (Thrift 2007), has contested the idea that emotions exclusively 'belong' to individual or collective actors (Massumi 2006; Protevi 2009). Ahmed (2004) explains that emotions are always oriented toward an object: something or someone is affecting us (makes us laugh, cry, or shiver). She writes,

So emotions are not simply something "I" or "we" have. Rather, it is through emotions, or how we respond to objects and others, that surfaces or boundaries are made: the "I" and the "we" are shaped by, and even take the shape of, contact with others. (Ahmed 2004, 10)

Circulating objects of emotions are called affects. Affects transform the capacity to act, not through cognitive work (as social movement theorists assume) but through precognitive, sensual, aesthetic, and intuitive effects (Clough 2007). In analyzing the role of fear in youth citizenship practices, we focus on these aesthetic relations, which are particularly salient in urban settings. However, the peculiarity of the 'risky' activities our informants chose to practice also calls for a discussion of emotional management and regulation (as suggested by social movement theorists). ${ }^{5}$

Among the 'risky' activities considered here, lifestyle sports have grown in popularity in North America and Europe since the late 1980s (Wheaton 2004; Lyng 1990; Allman et al. 2009). Lifestyle sports are linked to an ideology promoting fun, self-realization, and living in the present moment. They require a technical know-how about controlling one's environment, body, and emotions.

According to the risk society framework (Beck 1992), being aware of risk in modern society results in the need to control it and reduce its scope. West and Allin (2010) use this 
approach to show that mountain climbers are less interested in the thrill produced by the experience of risk, than by the control over risk they exercise through practicing the sport. In this context, their relation to risk and fear fosters a specific identity for climbers who see themselves as holding an uncommon know-how. This know-how constitutes what some would call a 'subculture', or what we call here a group identity enabling youth to present themselves as anti-conformist.

While the informants in our study acknowledged that the activities they take part in do present a certain degree of risk, for the most part they considered them to be safe because, through practice, they have learned to control hazards and gradually push their limits. Selfcontrol and work over oneself is central to mastering such techniques. We argue below that this is very much in line with the neoliberal context marked by the individualization of responsibility. In such a context, prudence more than risk-taking is required because, as Rose points out, it is considered an ethico-political duty to oneself and to others (Rose 1999; Grundy and Boudreau 2008; de Courville Nicol 2011).

Interestingly for this research, Lupton and Tulloch (2002) hold that voluntary risktaking occurs at a particular moment in one's life trajectory and suggest that the willingness to take risks is built through experience, interaction with others, and learning from different individuals. Participants in extreme sports search for an emotional intensity that would allow them to escape the alienation of daily life and live in the present moment.

Lyng (1990) explains 'high-risk' behavior as a constructed identity in a particular socio-historical period, highlighting the social dimensions of individual risk behavior. The term 'edgework' describes an activity associated with a threat to the physical or mental well-being for the participant, practiced by individuals with a particular technical expertise who experience a series of subjective sensations while practicing this activity (feeling of self-realization and omnipotence). Fear is part of the experience of edgework and overcoming this fear opens the door to rewarding sensations. Edgework would thus counterbalance the alienation felt by an individual by allowing him/her to experience a very intense sense of 'self' and completely freeing him/herself from societal pressures. Lyng (1990) concludes that edgework is a form of experimental anarchy through which individuals are pushing the boundaries of social conventions to explore the fringes of reality and fulfill their planned quest of authenticity (see also Ferrell 1993 concerning graffiti). We come back to this aspect later, as it is central to the unfolding of citizenship practices.

\section{'Living on the edge' in Montreal}

To gain greater in-depth knowledge about the relationship voluntary risk-takers have with risk, fear, and citizenship without being limited to the boundaries of a specific subculture, we decided to cover different activities that pose legal, physical, social or moral risks. We did not intend to create a representative sample, but rather to constitute a good exploratory lens to reflect on how fear is linked to urban political practices. The sample is composed as follows: a highliner, ${ }^{6}$ a BMX professional, ${ }^{7}$ three graffiti artists/taggers (including one who lived on the street for a short period of his life), two Greenpeace activists involved in urban climbing, two activists who do COP-watching, ${ }^{8}$ and two dumpster divers. ${ }^{9}$ Out of the 11 participants, 9 were males and 2 were females and their ages ranged from 20 to 40 years. ${ }^{10}$ Five of them were under 30 years of age and six were older. They mostly come from middle-class families, even though many of them have experienced financial difficulties at some point in their lives given their unconventional lifestyle choices. ${ }^{11}$ 
The recruitment of participants began with identifying people who take part in activities where there would be some interaction with the police and other authorities. Initial contacts were made by attending a vigil in honor of Freddy Villanueva, an 18-yearold who was shot by a police officer while he sat in a park with his friends in August 2008. At this gathering we met some of the key informants involved in organizations who work to combat police brutality. Other informants who we thought would elicit precious insights were graffiti artists, some of whom we met during the annual graffiti festival 'Under Pressure' held in downtown Montreal each summer. Contacts through acquaintances and informal observations also led to interviews with graffiti artists and those who practice the lifestyle sports discussed in this article. Our contacts also prompted us to consider activities that we had not initially thought of, such as dumpster diving. We decided to include this in the study as the participants' narratives demonstrate an interesting alternative view of mainstream society.

Most of the participants stated that they identified with an international community of practitioners, with specific attachment to their local community members. As Wilkins $(2008,3)$ notes, 'young people use cultural symbols to establish group membership, to make their lives more tolerable or interesting, and to resist aspects of the mainstream that are constraining or from which they are already excluded.' In addition, voluntary risktaking is not a practice attached to a specific local history. It takes place in similar ways in many other cities. However, the specificity of Montreal is considered important when youth are faced with the legal consequences of their acts. The structural climate of trust toward the police institution in Canada (even if there are severe criticisms concerning police abuses) translates into a conjunctural trust relationship between youth and the police (Boudreau et al. 2012). As one Greenpeace activist told us, it is easier to deal with the police in Montreal than elsewhere in the world. ${ }^{12}$

\section{The role of fear in individual and collective identity construction}

The majority of the participants interviewed do not see themselves as taking risks in choosing their activities and lifestyle. On the contrary, when asked about the risk involved in what they choose to do, many stated that there is risk involved in everything we do 'from coming into this world to crossing the street on a red light' (Michel $\left.{ }^{13}\right)$. They insisted that it provides them with a feeling of living life to the fullest. This idea was most eloquently explained by Michel, a highline professional:

You gotta experience life. I mean sure I'm turning upside down on top of cement. I wouldn't necessarily choose to install my line over cement. But I think the presence of danger brings you a certain awareness and I find bliss in this awareness. Sometimes I walk hundreds of feet off the ground unattached to my line and never do I feel so alive. I think when you feel that threat of death or danger it puts you completely in the moment where you really need to be ultimately focused on what you are doing. I find bliss in ultimate focus.

Michel's statement illustrates Lupton and Tulloch's (2002) point about the pleasures of voluntarily taking risks, whether in sports or other 'illegal' activities. According to these authors, voluntary risk-takers downplay the risks involved, which makes what are they doing seem less dangerous to them. This is further exemplified by Cedric, a pioneer of the graffiti scene in Montreal:

If you are talking about doing graffiti illegally then there is the risk of getting caught and being pursued legally. The risk is "getting caught" but the legal pursuit - if its municipal or civil court - is a slap on the wrist. It's a fine. If you're not being pursued criminally then you are at 
no risk of a criminal record. You're at no greater risk than getting a parking ticket or a speeding ticket.

The majority of participants explained that they are able to manage and control risks through practice and calculated gestures. For example, when asked to define risk, Julien who has practiced BMX competitively, told us that it means trying something that you have never done before. However, he goes on to say that when you reach a certain level of professional practice, the chances of getting hurt are greatly diminished. In his words,

If you are capable of doing certain tricks, then you will just add a variant to it, which makes it new. You know that you are already comfortable doing that, so just adding something will be dangerous, but you know that you have better chances of getting it. And when you reach a certain level you are able to have more control when you fall.

When it comes to climbing buildings for Greenpeace, including important political buildings, Antoine stressed that 'it's only risky if you lose control of your actions and if you don't think through what you are about to do'. He goes on to say that it is necessary to remain calm and think clearly in order to avoid losing control - loss of control can be caused by trying to climb too quickly or by panicking. Therefore, it involves countless hours of training and in-depth knowledge of the techniques and equipment used by Greenpeace, which increases one's level of self-confidence. The value of 'keeping control' provides arguments for justifying these practices with regard to mainstream society, as it conforms to the dominant cultural norms of individual responsibility.

In contrast, the arguments developed by the police and city authorities pertain to the uselessness and 'irrationality' of such risky behavior. This is most evident in the elaboration of the category 'at-risk' youth, which informs police action in Montreal. For police and city authorities, being 'at-risk' refers to youth's inability to take control over their life, their inability to extract themselves from a spiral of violence and drug addiction (Boudreau 2013).

There is, of course, important power differentials between middle-class white youths voluntarily taking risks and stigmatized and racialized youths involuntarily categorized as being 'at-risk'. Similarly, voluntary risk-taking is perceived to be less dangerous than imposed risk-taking (Lupton 1999). The contrast between police/state and youth perceptions of risk-taking is nevertheless worth noting. For many youths, going beyond personal limits is felt as empowering. As Michel explains, fear is a motivational factor in pushing oneself to the limits and to surpass one's abilities:

Fear is a healthy sensation. Without fear we would be in grave danger. So my personal philosophy on fear is: accept it, embrace it, appreciate it, but don't let it hold you back from doing what you know you're able to do. [...]

Interviewer: So you have confidence in yourself?

Michel: Ultimate. It made me grow into loving what really makes me scared.

According to Lupton and Tulloch (2002), venturing out of one's comfort zone to take risks enables deeper knowledge of oneself and, ultimately, the ability to reach a higher level of consciousness. As Antoine mentioned 'climbing is important for personal development, you push your limits.' Or similarly, Michel says:

The beauty of being scared is that you're pushing yourself past your capacity. In your practice you're growing as a human so when you go past your fear you're growing and growing is what I believe is the reason for our existence. To live, to love, to enjoy, and to grow.

Thus, some voluntary risk-takers see themselves first and foremost as professionals who, in order to excel in what they do, need to push themselves beyond their personal limits and 
overcome their fear. They use the feeling of fear to their advantage as a driving force to improve themselves. For some of our informants, fear and adrenaline provided a necessary channel for expressing themselves. MAN, ${ }^{14}$ a graffiti writer who lived on the street for a short period of time, also explained that graffiti is what allowed him to keep his sanity.

However, Thomas, another graffiti artist spoke about an aversion to the feeling of fear and the stress involved with the possibility of getting caught by the police or being attacked by other taggers for trespassing on their turf. Although he was caught by the police only once and even developed a unique way of avoiding getting caught (wearing a business suit and holding a briefcase) while tagging in broad daylight, he eventually stopped because he did not like the feeling of stress. As he explains, 'I don't like this stress. I did it because I wanted to prove things, but once they were proven, I didn't need it anymore.' He needed to work with the stress caused by fear in order to gain selfconfidence ('to prove things') and construct his identity. But, as he says, once he did not feel 'excluded anymore', he stopped tagging.

Indeed, some of the participants told us about the adrenaline rush and the thrill associated with the activities they do. While the search for this feeling was not necessarily a motivational factor for doing what they do, it certainly did have a positive effect on them in terms of self-confidence and stress relief. As MAN says, 'Before doing it you are anxious, while you are doing it, you are thrilled, and after you can breathe, let go a certain form of energy.' Cedric, another graffiti artist, emphasized the role of 'insecurity' in identity construction and self-confidence:

It's just a personal choice. If anything, I would say that insecurity has more to do with graffiti or trying to find yourself and find an identity for yourself. Being insecure has more to do with acts like that because we'll be doing things that we're less comfortable with because we want to live up to certain expectations or impress somebody. Especially when it comes to youth it's about insecurity and identity, more peer pressure.

These examples reveal two types of attitude toward social control in the contemporary North American context characterized by the 'fear of fear'. Stearns (2006) explains that American attitudes toward fear changed dramatically in the twentieth century. In contrast to nineteenth century injunctions to master fear with courage, 1920s behavioural psychologists began to call for fear avoidance. Fear was to be negated because it 'inhibits' rational reactions to problems and may cause long-lasting psychological damage. Fear came to be associated to children, and consequently, teenagers became eager to show they have no more fears as they grow up. The consequence of this was that fear came to be regarded as an 'attack': 'the need to deal with intense fear would come as a true surprise, and could be bitterly resented' (Stearns 2006, 109). Politically, this was translated into the acceptance of '[a]ny measures possible against the perpetrator of fear' and the 'need to memorialize occasions of fear,' as we have seen with Ground zero. Socially, it led to the belief 'that individuals should not have to handle fear on their own' (ibid: 110).

In such context marked by the valorization of prudence and the negation of fear, practicing 'risky' activities may be interpreted as a form of transgression. Transgression engenders anti-conformist identities. At the same time, the contemporary 'fear of fear' promotes 'taking risks' because it unleashes creative potentials (Grundy and Boudreau 2008). De Courville Nicol synthesizes this apparent paradox between these two attitudes toward social control:

I have suggested that some emotional economies are characterized by the greater promotion of opportunities for exercising self-discipline, where subject's relationship to norms is governed by a logic of compliance with a command (a logic of transgression, of law and order, and of immoral powerfulness), while others are characterized by the greater promotion of 
opportunities for exercising self-realization, where subject's relationship to norms is governed by a logic of favorable measurement to an ideal (a logic of inadequacy, of grades and examinations, and of immoral powerlessness). (de Courville Nicol 2011, 188)

Our informants constantly navigate between these two logics: (1) they ambiguously exercise self-discipline (through practice, in order to master the technical know-how, they evaluate risks and cautiously elevate its level); while (2) justifying their 'risky' choices with ideas of self-realization (emphasizing their achievements and the self-esteem developed through their practice). This combination of self-discipline and self-realization leads to different forms of empowerment. Again, using de Courville Nicol's (2011) categories, they might feel empowered biologically upon achieving a specific prowess, and subjectively when they know they are recognized by their peers. The argument we are advancing here is that despite the apparent moral conflict between their decision to voluntarily take risks and the prevalent social injunctions to avoid fear (Stearns 2006), these alternative lifestyles unleash not only biological and subjective empowerment, but also what de Courville Nicol would call moral empowerment, or what we call here empowering citizenship practices in order to emphasize the political relation at play. Challenging oneself goes in pair with proving oneself in order to be recognized as a social actor. Let us now turn to a discussion of how becoming a social actor can be politicized and understood as a form of citizenship act.

\section{Relationship to the state/authority/police}

If youth's relation to risk and fear corresponds to what the literature on extreme sport tells us, what is much less explored in this body of literature is youth's relation to authority. As mentioned earlier in this article, youth are often considered to be 'dangerous' and hostile to authority. They can be a source of fear if they are seen as disturbing the established order. Many of the participants in this research have had various encounters with police officers or municipal authorities given that some of their activities are illegal in one way or the other - because they illegally use urban objects such as trees, buildings, stairs, because they illegally occupy a space (private property, an abandoned building, a historical monument in the case of graffiti and Greenpeace climbing), because they take something that is considered private property (leftover food), or because they film without authorization. Some of them have had to face consequences, such as fines or imprisonment, while others never got caught.

As the participants recounted their experiences with the law, they explained how they developed strategies to avoid getting caught. Julien explained: that

you do your moves as fast as possible, you film it and then you leave. And if you have to run away from the police it's even better [because of] the adrenaline! It's exactly the adrenaline trip that makes it fun. Avoiding getting a ticket while you did your move is the ultimate.

At the same time, Julien and our other informants were not particularly worried about the consequences if they did get caught by the police, or at least justified their activities through other arguments. They did not think that they would get arrested and figured that they might only get a fine or even just a warning (see also Le Breton 2004). Cedric was arrested and sued for a quarter of a million dollars for having tagged railway property. He decided to face the police when they arrived and challenged the law. He recounted:

That is more about being an advocate or being an activist when it comes to something. The only thing we were guilty of was trespassing. The thing about graffiti is that you have to be caught in the act. If you're not caught in the act everything is hearsay. There is no proof that it was me who did it. When you know those things, there is no risk. 
These findings indicate a mode of interaction with the police characterized by avoidance, yet at the same time they found ways to avoid legal problems through negotiation. They see the police as just 'doing their job', as Julien puts it clearly:

Well, they don't have a choice to do their job. I have nothing against them, I'm not an anarchist. The police doesn't have anything against people who do those activities, they like it

(BMX and skateboarding) and they watch it on TV, but they have a job to do.

Most of the participants believe that by being respectful with police officers and remaining calm they will avoid further problems. This corresponds to a negotiated mode of interaction with the police and corroborates our findings with 'at-risk' youth (Boudreau et al. 2012). Consider these two citations:

Antoine: But it's important to stay cool or stay calm and be respectful to them, because if you don't handle your emotions or resist too much, then you give them right to use force.

MAN: There is no point hating cops or the government, it won't change who they are. But showing them there is other ways to control yourself than using fear might be more efficient. Like, you don't have to stereotype me.

However, most of the interviewees had a critical vision of police officers, agreeing that their intervention often creates more problems than solving them, or, in MAN's words: 'The problem with the police is that they don't know the street very well. They most of the time create more problems than they solve. They are not respected because they have power and they use fear.'

We did come across rather different experiences in our interviews with Greenpeace activists, which is not surprising given the crackdown on activists in the recent context of social unrest. Moreover, in the context of the student movement in Montreal which was unfolding during our fieldwork, the government has voted a crackdown legislation severely restricting street demonstrations. In their interactions with police, the Greenpeace activists often experienced verbal abuse at the hand of officers telling them to 'get a job' and 'find something better to do with their lives'.

Nevertheless, these voices expressing the reasons for choosing these 'risky' activities (from extreme sports to graffiti and activism) and their relation to authorities, lead us to suggest that youths who choose to voluntarily take risks have a greater sense of empowerment than other youth given the sense of self-realization that comes with their practice. Moreover, their anti-conformist identity supports their feeling of not being particularly threatened by the presence of any form of authority. This has important consequences on how they politicize their encounters with the State and other authorities.

\section{Citizenship practices}

When considering youth citizenship practices, it is important to use a broad definition of political action. Based on our previous work with youth and domestic workers (Boudreau, Boucher, and Liguori 2009), we prefer to speak in terms of political engagement, rather than in terms of political action or participation. The term 'engagement' implies a relation between the actor and the environment of action. Cedric puts it marvelously: 'The moment your awareness kicks in whatever you're exposed to at that moment, that's what you're going to adhere to. If you're not aware of the things influencing you, then they can't shape you.'

A person will engage with his/her milieu if it provides a positive feeling. Thus, being politically engaged means much more than voting or taking to the streets in a demonstration. It means engaging with one's milieu in order to affect it, to change it, but 
also to change oneself. A first level of political action refers to a basic interest for what is happening beyond one's immediate comfort zone (being curious about other people's lives). In dumpster diver Justine's words, it is all about the 'capacity to marvel at what comes to you.'

At a second level, being politically engaged entails awareness of publicly discussed issues (such as pollution or racial profiling). Nathalie, another dumpster diver explained to us that a 'good' citizen is someone 'who stays informed about what is going on outside of his/her life.' This level of political engagement was present in most of our interviews.

A third level of political engagement requires the ability to critically reflect and formulate opinions on these social issues. Through their choice of non-conformism, all our informants developed critical opinions of the mainstream. Antoine, for example, told us that a 'good' citizen is someone who 'respects the good laws, the just laws.' When prompted on what he means by good and bad laws, he said that a 'good law or system puts people before profit. So I don't like the laws that favor corporations and give them unlimited access to anything they want to the detriment of the population.' Each of our informants formulated such opinions with regard to what they felt are social problems: police brutality, hyper consumption, pollution, poverty, parental violence, and so on.

Some informants maintained a conflicting relationship with the mainstream. But most of them jumped to the fourth level of political engagement, showing empathy for others involved in such social issues. Cedric rejects the contentious understanding of politics very clearly, developing what we have called an intersubjective form of citizenship practice:

It's [graffiti] not about legality or illegality. It's about ego and ignorance, individual, identity. It's a choice. It's about establishing yourself within a group of peers. It's not against the system. This isn't about politics changing the world, it's about writing your name on a wall. It's not about freedom of speech. It may be for some graffiti writers depending on where you live and if you have no rights. It has to be case per case. Each context is completely different.

For him, 'good' citizenship is

about awareness. If you're tagging on someone's building at the end of the day it's easy to clean off, not a big deal. But what if the owner is an 85 year old woman who just lost her husband and she is alone and nobody is there to help her. Imagine if someone did that to your grandmother? So why not see this woman as your grandmother. You can go make it right, clean it or fix it at least, so that you can make a contribution. You can do that at any age.

As Antoine said, 'I don't know if I am a good citizen, but I try to be a good person.' At this fourth level, political engagement is transformed from a more abstract relation to institutions (to the system, to the mainstream) expressed in political opinions, to a more personalized and intersubjective engagement with others ('being a good person', 'awareness'). Our informants were aware of power relations involved in these intersubjective relations. But as MAN explains, power is not something to be grabbed. It is not where people think it is. In the following statement, he expresses in his own words what we describe later as situations of actions, where fear and power flow between people as their interaction unfolds.

MAN: With men and women that are in some sort of demand of power is enough to drive people crazy. They are looking for power in the wrong places. Respect is something out of love, they are going more for fear, which they confuse with respect. It's like gangsters. One sets fear on the other and the other one backs away. I'm not scared by that. I'm not scared of fear.

Interviewer: But you do have fear?

MAN: Yes all of us have fear, but what I like to do is understand the fear. 
MAN displays a Foucaldian view of power unfolding through social relations. Power, he says, comes with 'love' and 'respect' more than with the manipulation of fear to control others. He shows how acting politically (being empowered as a political member of the polity; being a good citizen) is fundamentally an intersubjective practice involving what he calls love and respect.

Explicit forms of political actions such as activism would constitute a fifth level of political engagement. In their own ways, most of our informants are activists, whether for Greenpeace or a collective against police brutality (most explicitly), but also through their ideologically justified lifestyle choices (dumpster diving, sometimes graffiti).

Being politically engaged, even at the basic first level, rests on a sense of empowerment. Our informants have gained a sense of empowerment through their chosen lifestyles. Not all of them show a fifth level of activist political engagement, but their choice of non-conformism necessarily brings them to critically reflect on the mainstream (level 3). As Michel puts it, 'Have fun. Push yourself. Live. Breathe. Just let go of that ideal that the normal everyday society pushes on you to get a job and do what you are told.'

\section{Discussion: fear and urban citizenship practices}

These brief encounters with youth who engage in voluntary risk-taking activities and choose alternative lifestyles in Montreal illustrate how fear can become an empowering energy for action. Fear can be used as an instrument of action, either because it is manipulated by authorities or because it energizes citizenship practices. When, for example, a group of racialized youth is depicted as 'dangerous', a discourse of fear is constructed and manipulated for exclusionary purposes. We have tried to show here that such a conceptualization of fear as a manipulated political instrument is insufficient to understand how it operates in the city. The fact that youth are the target of surveillance and disciplining programs because they generate fear is only one side of the coin. The manipulation of fear entails seeing fear as something to be used in order to provide power, as described by MAN above.

In contrast, among voluntary risk-takers, empowerment largely comes from technical know-how (and ensuing self-confidence and feeling of competence) resulting from experience and shared information within a group of pairs practicing the same activity. Being able to take risks and avoid their consequences is proof that one masters this subcultural knowledge and is part of the group. In this sense, fear is seen as energy to be controlled through self-discipline. This is the main idea of fear we encountered in our conversations with youth. In their 'risky' activities, they seek to transform the fear they experience into pleasure (de Courville Nicol 2011). Fear for them takes on a positive connotation, providing an 'adrenaline rush' or generating security because 'fear makes you more vigilant' (Antoine). For them, fear is to be overcome through practice, training, and vigilance. Once you succeed in transforming fear into energy for performing better, it provides a sense of self-confidence and self-realization.

Through their practices, these youth contest the fear of fear itself. Thus voluntary risktakers turn fear, which is culturally conceptualized as a negative feeling, into something positive: rather than an instrument to exercise power over others (as seen in the stigmatizing and manipulative discourses of fear), fear is seen as an instrument to exercise power over oneself (empowerment). This has been studied by social movement theorists, but their focus is on facing fear to gather the courage to act, more than for self-realization (Glazer and Glazer 1999; Rachman 2004). 
Our informant's conceptualization of fear points to a mix of modern and advanced modern understandings of the subject. The modern subject functions through selfdiscipline in reaction to the fear of shame. This is seen in the judgments expressed by our informants concerning peers who 'took unnecessary risks,' do not have sufficient technical know-how, or 'confuse [fear] with respect.' In contrast to the modern subject, the advanced modern subject is more concerned with personal insecurity and functions through self-realization in order to experience positive emotions such as self-esteem (De Courville Nicol 2011). Our informants express both self-disciplining (motivated by the fear of shame) and self-realization (motivated by the fear of insecurity and the search for self-esteem through performance).

As energy for action on others (through manipulation) and on oneself (through selfdisciplining and self-realization), fear nurtures both a modern and advanced modern 'heroic' conception of the self. The hero, understood as an autonomous and free-standing individual with internal energies, acts because she/he thinks she/he can affect a situation (Boudreau and de Alba 2011). But the hero's relation to fear changed as the 'fear of fear' came to be culturally prominent in North America. The modern hero is courageous and must overcome fear to rescue someone. For the advanced modern hero, to the contrary, fear cannot be overcome because it is absent. Stearns (2006) shows how Batman, Spiderman, or Superman do not master their fears like a knight would do in facing the dragon, they simply do not experience fear. ${ }^{15}$

Whether modern or advanced modern, the point we wish to make here is that young people do not simply seek to construct themselves as self-contained individual (heroic) actors through self-discipline and self-realization. An important aspect of their practices is the constitution of alternative group identities. They practice these 'risky' activities because it provides them with a sense of community (Becker 1963; Wilkins 2008). Membership in a group with an alternative lifestyle legitimates their anti-conformist ideas and enables them to experiment with 'anarchy' (Lyng 1990).

This is why it seems important to go beyond the anthropocentrist or psychologyoriented literature on fear (including the social movement literature exploring this emotion). For our informants, fear acts through 'affective atmospheres' (Anderson 2009). It envelops them and radiates from them. In fearful situations of action such as climbing buildings or diving in a dumpster, the idea of free-standing, autonomous individuals remains only in the background. The autonomous heroic actor is transformed into a subject constitutive of a situation of action. In other words, the citizen-actor and his/her selfrealization becomes less important than the citizenship act and its unfolding.

When in a specific moment and place something happens (for instance, escaping from police officers when painting a graffiti), actors engage in the situation by giving it a shared meaning (i.e., the fear/thrill of escaping). Participants involved in this particular situation designate this moment as important (they will remember it, describe how it unfolded, what route they took to escape, how they felt). By doing so, the situation becomes recognizable and individuals as much as objects participate in a form collective situated action. ${ }^{16}$

In situations of action, the analytical focus is no longer how individual 'heroic' actors overcome fear or seek self-realization, but rather the situation itself (what happened, when, where, how why). Fear is thus seen an affective flow in a specific moment and place and participates in constructing situations of action. The cumulative effects of such situations of action construct a common group narrative. Fear thus participates in group identity and empowerment.

When fear is conceived as an affective flow active in specific situations, it empowers through aesthetic mechanisms. In fearful situations of action such as those described by 
our informants, the object of fear (being caught, being hurt, being negatively judged, being rejected, being ignored) circulates and affects the people and objects involved in the situation. It connects actors to one another and to objects 'without words' (or better put, without cognitive work) simply through mutual bodily attunement. By experiencing such situations of common fear/thrill, youth construct a group identity, mutually adjust to one another through intuition and emotional cues, and develop ways of acting that are specific to them and the situations they collectively create. This provides a strong feeling of empowerment, as Nathalie told us. ${ }^{17}$

This group aesthetic develops over time among mutually recognized anti-conformist peers who share similar affective memories. Nathalie, for instance, described to us how she likes to explore abandoned urban buildings, even if she is trespassing private property. For her, such beauty can only be accessed by 'breaking authority' and communicating with others who are sensitive to such beauty. Sensitive is a key word here: Nathalie explains how shared affective memories, or what Katz (1988) calls 'aesthetic finesse,' requires being able to recognize and elaborate upon the sensual potentialities of a situation. Acquired through embodied practice and experience, this shared, pre-cognitive affective skill develops as individuals share fearful situations of action.

For example, when Greenpeace activists describe their encounters with police officers, they speak of various intuitions with regard to who will help them or cause more nuisances. Marc explains that first line police officers and security guards are always more nervous, while it is easier to deal with sergeants and lieutenants:

Well, patrollers lose control. They don't understand what is happening and they don't know how to negotiate or interact with activists. They react brutally. I suppose this provides with a sense of authority.

Such aesthetic finesse reveals Marc's affective memory of past encounters with state authorities and shapes his relation to them. In other words, fearful situations of action affect citizenship practices. In their relation to the state or other authorities, youths do not simply claim rights or resist power and domination, they also negotiate a space of action by building on their aesthetic finesse and affective memory.

\section{Conclusion}

In sum, we suggest that youth experience with 'risky' activities initially creates a feeling of 'displacement' (feeling threatened). Through modern and advanced modern 'heroic' will, efforts, and self-discipline, they ultimately succeed in overcoming or ignoring this internal feeling of fear. Such success provides very positive emotions of self-realization. In addition to this personal challenge, their activities provide them with group empowerment because of the collectively felt feeling of fear in specific situations of action. This affects how they interact with the state. Some of them do so through claimmaking and contention, such as Greenpeace activists, but all of them also interact through negotiation using their aesthetic finesse.

We have argued that in a context where fear is culturally conceived as something to avoid, voluntary risk-taking is not to be interpreted as social and political 'opting out.' Le Breton (2004) and Katz (1988) have shown how such behavior is in fact a call for social relation. When they were asked where they thought they would be in ten years, most of our informants figured themselves in a situation where they could still practice their 'risky' activity in the most socially accepted way (for example, slacklining in a circus or painting graffiti in a gallery). Many of them expressed their desire to share their experience in an 
educative way. Thomas works with youth organizations using graffiti as delinquency prevention techniques; Nathalie explained she could only see herself as a freelancer or working for a non-profit organization with kids; Antoine and Marc already work on changing people's perception of the environment through political actions with Greenpeace; and MAN said he wants to offer people he meets the opportunity to discover a new world and culture through his graffiti, street art, and underground punk music production.

We further suggest that these 'risky' practices should be understood as a political relation to the state, as a form of citizenship practice that can be either solidaristic, agonistic, or aesthetic. In order to 'read' politics in these practices, we must first decenter our understanding of citizenship from the state (focusing also on intersubjective forms of political interactions). Second, we must adopt a situational approach by decomposing citizenship practices in numerous acts, rather than conceiving it as 'something' one possess (a legal status or membership in the polity). These two theoretical openings were initiated by the urban citizenship literature and many papers published in this journal. Our contribution here is to further nuance the types of relations citizens develop with the state.

Growing in maturity brought our informants to assume entirely the benefits and the consequences of their risk-taking activity. They chose this path or considered taking it because they refused the simple assumption that an illegal act is necessarily illegitimate. Having seen the benefits of this 'undesirable' activity on their life, their pursuit helped them in building a critical vision of the police and political institutions. In this sense, choosing an anti-conformist life transformed the way they perceive themselves as social and political actors.

\section{Acknowledgements}

This research was funded by the Programa Interinstitucional de Estudios de la Región de América del Norte (PIERAN). We thank Maria Moreno, Guénola Capron and Greig Chrysler for their joint work in this comparative project.

\section{Disclosure statement}

No potential conflict of interest was reported by the authors.

\section{Notes}

1. In this paper, youth is not defined by a specific age category, but as a social subjectivity. Is young whoever feels and acts as a youngster.

2. As further explained in what follows, fear is defined as the urge to overcome felt danger (de Courville Nicol 2011). It can take various forms such as terror, horror, stress, thrill, and so on.

3. We conducted 11 semi-structured interviews between January and November 2012, along with informal participant observation in public spaces in Montreal, either practicing slackline or marching on the streets during student demonstrations. Fieldwork was conducted during a very intense political moment in Montreal, known in French as the 'printemps érable'. What started as a massive student strike lasted over 5 months and evolved as a major socio-ecological contestation against neoliberalism and corruption.

4. As D. Harvey suggests:

The right to the city is far more that the individual liberty to access to urban resources: it is a right to change ourselves by changing the city. It is, moreover, a common rather than an individual right since this transformation inevitably depends upon the exercise of a collective power to reshape the processes of urbanization. The freedom to make and remake our cities and ourselves is, I want to argue, one of the most precious, yet most neglected of our human rights. (Harvey 2010, 23) 
5. We are thus proposing a tensed reconciliation of approaches with very different epistemological standpoints.

6. Highlining consists of stretching an elastic and dynamic rope between two high platforms, mountains, buildings or trees and to walk from one extremity to the order like a tight rope walker. The main difference is that the highliner does not use a pendulum.

7. A BMX professional is an athlete supported by private companies for giving shows and competing.

8. COP-watching consists of secretly filming police officers in order to produce evidence of abuse.

9. Dumpster diving is the practice of retrieving edible items from commercial trash to avoid food waste.

10. The gendered aspect of voluntary risk-taking is not discussed here, but remains central to understanding the relationship between fear, urban environments, and empowerment. For an excellent discussion, see Olstead (2011).

11. All of the participants (except for one) are white and from middle class backgrounds. This was a deliberate choice for methodological and analytical purposes given that we had already conducted research on the experiences of racialized 'at-risk' youth with the police (Boudreau et al. 2012). Our goal was thus to understand the experiences of white middle-class youth who voluntarily take part in 'risky' activities.

12. Antoine told us: 'I would be more worried if $\mathrm{i}$ was arrested in Russia where your rights are not guaranteed at all'.

13. All names are fictional.

14. Upon request from our informant, we kept his graffiti artist name.

15. In their analysis of the evolution of the Batman character in various movies from the 1980s and 2000s, Boudreau and De Alba (2011) show, however, how the fearless hero of the 1980s has been transformed into a non-hero experiencing intense emotional turmoil 20 years later.

16. Saville's (2008) work on Parkour enthusiasts illustrates, for instance, how practitioners 'let go of fear', how this sense of abandonment to the thrills entailed in the situation stimulates their imagination. Their relation to the urban built environment where they practice this sport then mutates in a creative appropriation of the objects.

17. 'In group, it is easier. And it is really convivial. It's a gang trip, exploratory.'

\section{References}

Ahmed, S. 2004. The Cultural Politics of Emotions. Edinburgh: Edinburgh University Press.

Allman, Tara L., R. D. Mittelstaedt, Bruce Martin, and Marni Goldenberg. 2009. "Exploring the Motivations of Base Jumpers: Extreme Sport Enthusiasts." Sport \& Tourism 14 (4): 229-247. doi:10.1080/14775080903453740.

Anderson, Ben. 2009. “Affective Atmospheres." Emotion, Space and Society 2 (2): 77-81. doi:10. 1016/j.emospa.2009.08.005.

Barbalet, J. M. 1995. "Climates of Fear and Socio-Political Change." Journal for the Theory of Social Behaviour 25 (1): 15-33. doi:10.1111/j.1468-5914.1995.tb00264.x.

Beck, Ulrich. 1992. Risk Society: Towards a New Modernity, 261. New Delhi: Sage.

Becker, Howard. 1963. Outsiders: Études de sociologie de la déviance. Paris: Éditions A.M. Métaillé.

Boudreau, Julie-Anne. 2010. "Reflections on Urbanity as an Object of Study and a Critical Epistemology." In Critical Urban Studies: New Directions, edited by Jonathan S. Davies and David L. Imbroscio, 55-72. New York: SUNY Press.

Boudreau, J. A. 2013. "Jeunes et gangs de rue : l'informel comme lieu et forme d'action politique à Montréal." ACME: Revue Électronique Internationale de Géographie Critique 12 (3): 520-550. www.acme-journal.org

Boudreau, J. A., and F. de Alba. 2011. "The Figure of the Hero in Cinematographic and Urban Spaces: Fear and Politics in Ciudad Juarez." Emotion, Space and Society 4 (2): 75-85.

Boudreau, J. A., N. Boucher, and M. Liguori. 2009. "Taking the Bus Daily and Demonstrating on Sunday: Reflections on the Formation of Political Subjectivity in an Urban World." CITY 13 (2-3): 336-346. doi:10.1080/13604810902982870.

Boudreau, J. A., D. E. Davis, N. Boucher, O. Chatel, C. Élizabeth, L. Janni, A. Philoctète, and H. Salazar Salame. 2012. Constructing Youth Citizenship in Montreal and Mexico City: 
The Examples of Youth-Police Relations in Saint-Michel and Iztapalapa, Research Report. Institut National de la Recherche Scientifique. ISBN 978-2-89575-267-7, 167 p. http://www.ucs. inrs.ca/sites/default/files/centre_ucs/pdf/MontrealMexicoCityreport.pdf

Clough, P. T. 2007. The Affective Turn: Theorizing the Social. Durham: Duke University Press.

Conway, J. 2004. Identity, Place, Knowledge: Social Movements Contesting Globalization. Toronto: Fernwood.

De Courville Nicol, V. 2011. Social Economies of Fear and Desire: Emotional Regulation, Emotion Management, and Embodied Autonomy. New York: Palgrave Macmillan.

Dikeç, M., and L. Gilbert. 2002. "Right to the City: Homage or a New Societal Ethics?" Capitalism, Nature, Socialism 11 (2): 58-74.

Ferrell, J. 1993. Crimes of Style: Urban Graffiti and the Politics of Criminality. Boston: Northeastern University Press.

Furedi, F. 2005. The Politics of Fear: Beyond Left and Right. London: Continuum Press.

Glazer, M. P., and P. M. Glazer. 1999. "On the Trail of Courageous Behavior." Sociological Inquiry 69 (2): 276-295. doi:10.1111/j.1475-682X.1999.tb00503.x.

Goguel d'Allondans, Thierry. 2004. "Pour trois grains d'éternité. Contribution à une anthropologie de la mort adolescente." In L'imaginaire urbain et les jeunes: La ville comme espace d'expériences identitaires et créatrices [Urban Imaginary and Youth: The City as a Space of Identity and Creative Experience], edited by Boudreault and Parazelli, 259-265. Montréal: Presses de l'Université du Québec.

Goodwin, J., and S. Pfaff. 2001. "Emotion Work in High-Risk Social Movements: Managing Fear in the U.S. and East German Civil Rights Movements." In Passionate Politics: Emotions and Social Movements, edited by Jeff Goodwin, James M. Jasper, and Francesca Polletta. Chicago, IL: University of Chicago Press.

Grundy, John, and J. A. Boudreau. 2008. "Living With Culture: Creative Citizenship Practices in Toronto." Citizenship Studies 12 (4): 347-363. doi:10.1080/13621020802184226.

Hamel, P., H. Lustiger-Thaler, and M. Mayer, eds. 2000. Urban Movements in a Globalising World. London: Routledge.

Harvey, D. 2010. "The Right to the City." New Left Review 53: 23-40.

Holston, J. 1995. "Spaces of Insurgent Citizenship." Planning Theory 13: 35-51.

Holston, J., and A. Appadurai. 1996. "Cities and Citizenship." Public Culture 8 (2): 187-204. doi:10.1215/08992363-8-2-187.

Isin, Engin F. 2008. “Theorizing Acts of Citizenship.” In Acts of Citizenship, edited by Engin F. Isin and Greg M. Nielsen. London: Zed Books.

Katz, J. 1988. Seductions of Crime: Moral and Sensual Attractions in Doing Evil. New York: Basic Books.

Köhler, B., and M. Wissen. 2003. "Glocalizing Protest: Urban Conflicts and Global Social Movements." International Journal of Urban and Regional Research 27 (4): 942-951.

Le Breton, David. 2004. "The Anthropology of Adolescent Risk-Taking Behaviours." Body \& Society 10 (1): 1-15. doi:10.1177/1357034X04041758.

Lupton, D. 1999. Risk: Key Ideas. London: Routledge.

Lupton, Deborah, and John Tulloch. 2002. "Life Would be Pretty Dull Without Risk: Voluntary Risk-Taking and its Pleasures." Health, Risk \& Society 4 (2). doi:10.1080/13698570220137015.

Lyng, Stephen. 1990. "Edgework: A Social Psychological Analysis of Voluntary Risk Taking." American Journal of Sociology 95 (4): 851-886. doi:10.1086/229379.

Marcus, G. E. 2000. "Emotions in Politics." Annual Review of Political Science 3 (1): 221-250. doi:10.1146/annurev.polisci.3.1.221.

Massumi, Brian. 2006. "Peur, dit le spectre." Multitudes 23 (winter): 135-152.

Mitchell, D. 2003. The Right to the City: Social Justice and the Fight for Public Space. New York: Guilford Press.

Olstead, Riley. 2011. "Gender, Space and Fear: A Study of Women's Edgework.” Emotion, Space and Society 4: 86-94.

Postrel, Virginia. 2003. The Substance of Style: How the Rise of Aesthetic Value is Remaking Commerce, Culture, and Consciousness. New York: Harper Perennial.

Protevi, J. 2009. Political Affect: Connecting the Social and the Somatic. Minneapolis: University of Minnesota Press.

Rachman, S. J. 2004. "Fear and Courage: Apsychological Perspective." Social Research 71 (1): $149-176$. 
Robin, C. 2004. Fear: History of a Political Idea. Oxford: Oxford University Press.

Rose, N. 1999. Powers of Freedom: Reframing Political Thought. Cambridge: Cambridge University Press.

Sassen, S. 1996. "Whose City is it? Globalization and the Formation of New Claims." Public Culture 8 (2): 205-223. doi:10.1215/08992363-8-2-205.

Saville, Stephen J. 2008. "Playing with Fear: Parkour and the Mobility of Emotion." Social \& Cultural Geography 9 (8). doi:10.1080/14649360802441440.

Sorkin, M., and S. Zukin, eds. 2002. After the World Trade Center: Rethinking New York City. New York: Routledge.

Stearns, P. 2006. American Fear: The Causes and Consequences of High Anxiety. New York: Routledge.

Thrift, N. 2007. Non-Representational Theory: Space, Politics, Affect. London: Routledge.

Ungar, Mark. 2009. "Policing Youth in Latin America." In Youth Violence in Latin America: Gangs and Juvenile Justice in Perspective, edited by G. A. Jones and D. Rodgers, 203-224. New York: Palgrave Mcmillan.

West, A., and L. Allin. 2010. "Chancing Your Arm: The Meaning of Risk in Rock Climbing." Sport in Society: Cultures, Commerce, Media, Politics 13 (7-8): 1234-1248.

Wheaton, Belinda. 2004. "Introduction: Mapping the Lifestyle Sport-Scape." In Understanding Lifestyle Sport: Consumption, Identity and Difference, edited by B. Wheaton, 1-28. New York: Routledge.

Wilkins, A. C. 2008. Wannabes, Goths, and Christians: The Boundaries of Sex, Style, and Status. Chicago, IL: University of Chicago Press.

Yang, G. 2000. "Achieving Emotions in Collective Action: Emotional Processes and Movement Mobilization in the 1989 Chinese Student Movement." Sociological Quarterly 41 (4): 593-614. doi:10.1111/j.1533-8525.2000.tb00075.x. 